\title{
Effects of extremely low frequency electromagnetic fields on growth, cytogenetic, protein content and antioxidant system of Zea mays L.
}

\author{
Azita Shabrangi ${ }^{1}$, Ahmad Majd ${ }^{2,4}$ and Masoud Sheidai ${ }^{3}$ \\ ${ }^{1}$ Islamic Azad University, Pharmaceutical Sciences Branch, Tehran, Iran. \\ ${ }^{2}$ Department of biology,Faculty of Biological Sciences, North Tehran Branch, Islamic Azad University, Tehran, Iran. \\ ${ }^{3}$ Faculty of biological science, Shahid Beheshti University, GC, Tehran, Iran. \\ ${ }^{4}$ Department of biological science, Faculty of science, Tarbiat Moallem University, Tehran, Iran.
}

Accepted 13 June, 2011

\begin{abstract}
Electromagnetic fields are an important environmental factor that can influence the growth and development of plants. Exposure to EMFs was performed by a locally designed EMF generator. Our investigations were focused on plants grown from wet pretreated seeds with 3 and $10 \mathrm{mT}$ for a $4 \mathrm{~h}$ exposure time and compared with the control plants. Different treatments differed significantly in morphological characters. Mitotic analyses indicated a positive influence of EMF on the rate of cell proliferation in pretreated seeds with $3 \mathrm{mT}$ intensity for a $4 \mathrm{~h}$ exposure time, and showed decrease in chromosomal aberrations. The reverse occurred in pretreated seeds with $10 \mathrm{mT}$ intensity for a $4 \mathrm{~h}$ exposure time. The mean value of total, terminal and intercalary chiasmata changed significantly in the plants grown from exposed seeds to $3 \mathrm{mT}$ intensity indicating that EMFs increases genetic recombination. A significant decrease in protein content of pre-treated samples as well as alteration in the number and intensity of bands was observed. EMFs with the magnitude of 3 and $10 \mathrm{mT}$ for $4 \mathrm{~h}$ caused significant increase in catalase (CAT) and ascorbate peroxidaes (APX) activities in both root and shoot tissues.
\end{abstract}

Key words: Zea mays, cytogenetic, protein content, antioxidant system, electromagnetic fields.

\section{INTRODUCTION}

In the natural environment, living things are exposed to abiotic stress induced by electromagnetic fields (EMFs) due to distribution of different kinds of instruments and equipments. This caused more concern about the risk of disorders in the function of biological systems. Several studies have been conducted to find out the effect of EMFs on the growth and physiology of the plants, nevertheless not much is known about the exact mechanism of action of EMFs in altering plant growth.

Many studies have reported the effects of magnetic field on variety of agriculturally important plants (Angel et al., 2005) such as studying effects of EMFs on seeds germination and seedlings growth and seed vigor (Bhatnagar and Deb, 1977; Moon and Chung, 2000;

*Corresponding author. E-mail: msheidai@yahoo.com.
Pittman, 1977; Shabrangi and Majd, 2009).

Magnetic fields affect the synthesis of DNA and RNA as well as the cellular proliferation. EMFs in both extremely low frequency (ELF) and radio frequency (RF) ranges activate the cellular stress response, a protective mechanism that induces the expression of stress response genes (Ruediger, 2009). A potential link between EMFs and its effects on living organisms is the fact that EMFs cause an oxidative stress that is, increase in the activity, concentration and lifetime of free radicals (Sen Gupta et al., 1993; Holaday and Allen, 1993; Tkalec et al., 2005). Consequently, EMFs alters gene expression, protein biosynthesis, enzyme activity, cell reproduction and cellular metabolism (Nirmala and Rao, 1996). EMFs cytological effects include changing the mitosis control mechanisms, increase in the percentages of chromosomal aberrations such as stickiness, bridges and fragments, lagging and disorganized chromosomes 
(Smith and Mays, 1984). This study considers the effects of EMFs as abiotic stress on the early vegetative growth,cytogenetic and activity of stress enzymes of maize plant (Zea mays L.). This would help us to improve general knowledge about mechanisms of the response of higher plants to EMFs.

\section{MATERIALS AND METHODS}

\section{Electromagnetic field exposure}

Exposure to EMFs was performed using a locally designed EMF generator. The electrical power was provided by a $220 \mathrm{~V}$ AC power supply (ED-345BM, China) with a variable voltage, current and fixed frequency $(60 \mathrm{~Hz})$. This system consisted of one handmade coil, cylindrical in form, made of polyethylene $12 \mathrm{~cm}$ in diameter and 50 $\mathrm{cm}$ in length. The coil was not shielded for electrical field and the seeds were exposed to both magnetic and electric fields generated by the coils.

Calibration of the system as well as tests for the accuracy and uniformity of EMFs $(60 \mathrm{~Hz})$ were performed using a tesla meter (516 62, LEYBOLD, Germany) with a B-probe type of hall sound. Applied magnetic field was measured to be from 1 to $10 \mathrm{mT}$, uniform at all points of samples.

A normal fan was employed to avoid any increase in temperature. The temperature was measured with a thermometer to be $22+1^{\circ} \mathrm{C}$. The power was $15 \mathrm{~min}$ on and $15 \mathrm{~min}$ off. The temperature was measured with a thermometer to be $22+1^{\circ} \mathrm{C}$. We measured the temperature of the middle of coil, where the samples were placed and the room temperature was $22^{\circ} \mathrm{C}$. When the power was on, the fan worked to lower the temperature, which increased up to $1^{\circ} \mathrm{C}$.

The B-probe dimensions without the stand rod was $40 \times 35 \times 340$ $\mathrm{mm}$ (516 60, LEYBOLD, Germany). An electrical current of $60 \mathrm{~Hz}$ was used to generate the magnetic field in the coil and the magnitude of magnetic field calculated from $B=\mu{ }^{\circ} \mathrm{I}$ and measured by probe were in very good agreement.

Seed treatment was carried out during day light. Seeds of $Z$. mays L. (genotype = single cross 704 ) were obtained from seed and plant improvement institute, Karaj, Iran, which were selected for a uniform size, shape and equal average weight. Three replicates were used in the experiment with 30 seeds in each treatment. In case of wet seeds treatment, the seeds were spread on the moist filter papers in Petri dishes and then placed in the middle of a horizontally fixed coil. Untreated seeds were used as control under similar condition. The wet and dry seeds were exposed to EMFs by a magnitude of 1 to $7 \mathrm{mT}$ in steps of $2 \mathrm{mT}$, till the highest intensity of $10 \mathrm{mT}$ for 1 to $4 \mathrm{~h}$. One hour intervals were used. Then difference among the seedlings grown from treated seeds as well as control seedlings was determined by Analysis of Variance Test (ANOVA), followed by Duncan's multiple range test. The most and least significant growth of seedling were chosen for cytogenetics study and enzymatic activity assay. Seedlings grown from wet pretreated seeds with $3 \mathrm{mT}$ for $4 \mathrm{~h}$ showed the most growth and seedlings grown from wet pretreated seeds with $10 \mathrm{mT}$ for $4 \mathrm{~h}$ showed the least growth (considering growth parameters including seed germination, root length, shoot length, fresh biomass, dry biomass of 7 day seedlings). Untreated seeds (sham) were used as control under similar condition. It means they were placed in the similar coil but not connected to the power.

Petri dishes were placed in a seed germination chamber at $23^{\circ} \mathrm{C}$ with a photo period of $14 \mathrm{~h}$ day/10 $\mathrm{h}$ dark, and watered daily at relative humidity $(\mathrm{RH})$ of $20 \%$. The number of germinated seeds was recorded on the 5th day after watering and 7-10 day old seedlings from each replicate were randomly chosen for shoot and root length as well as fresh weight measurements. Subsequently, seedlings were dried in oven at $62^{\circ} \mathrm{C}$ for $48 \mathrm{~h}$ and dry weights were measured. Treated and untreated (control) seeds were grown in the field. Wet seeds were treated with 3 and $10 \mathrm{mT}$ for a $4 \mathrm{~h}$ exposure time.

\section{Morphological study}

Morphological characteristics including the number of internodes, number of leaves, number of tubular leaves covering the corn, mean number of rows in each corn, 100 seed weight, fresh biomass weight and dry biomass weight in both root and shoot tissues were studied.

\section{Cytogenetic studies}

For mitotic analysis, freshly grown roots were cut and fixed in Carnoy's solution ( 3 volumes ethanol: 1 volume glacial acetic acid), then placed in refrigerator at $4^{\circ} \mathrm{C}$ for $24 \mathrm{~h}$ and then stored in $70 \%$ ethanol at $4^{\circ} \mathrm{C}$. Root tips were hydrolyzed in $1 \mathrm{~N} \mathrm{HCl}$ at $60^{\circ} \mathrm{C}$ for 15 min, stained using squash technique with acetocarmine as the stain and examined microscopically. Cytogenetic parameters including mitotic index (Ml\% that is, total cells in division $\times 100 /$ total cells analyzed) and the chromosomal aberration index (Al that is, total chromosomal aberrations $\times 100 /$ total cells analyzed) were determined.

For meiotic analysis, young flower buds were collected from 10 randomly selected plants grown from treated seeds as well as control plants and fixed in acetic acid absolute ethyl alcohol (1:3 $\mathrm{v} / \mathrm{v}$ ) for $24 \mathrm{~h}$. Flower buds were then stored in $70 \%$ ethanol at $4^{\circ} \mathrm{C}$. Squash technique and aceto-orsein staining was used for cytological studies (Sheidai et al., 2001), chromosome pairing and chiasma frequency was determined by using minimum 100 meiocytes showing diakinesis/metaphase-I stages, while chromosome segregation was studied in minimum 100 anaphase-I and II stages.

\section{Gel electrophoresis}

The gel electrophoresis of total protein was performed on 7-day old seedlings grown from treated seeds showing the best growth conditions and also in control plants. These seedlings were grown from wet pretreated seeds with 3 and $10 \mathrm{mT}$ both for $4 \mathrm{~h}$ exposure time. Seedlings $(5 \mathrm{~g})$ were homogenized in $2 \mathrm{ml}$ of cold Tris buffer $(\mathrm{pH}=8.2)$ containing 1\% PVP and centrifuged at $40,000 \mathrm{~g}$ for $30 \mathrm{~min}$ at $4{ }^{\circ} \mathrm{C}$. Protein extracts were mixed with an equal volume of the sample loading buffer and incubated for $5 \mathrm{~min}$ at $100^{\circ} \mathrm{C}$ and then were loaded on the gels. Marker proteins (LMW Calibration Kit, BioRad) were also run on each gel. Total protein concentration was assayed by the Bradford (1976) method. The protein composition of the extracts was analyzed under reducing conditions by the SDSPAGE. Electrophoresis was performed at a current of $15 \mathrm{~mA}$ per stacking gel and $25 \mathrm{~mA}(300 \mathrm{~V})$ for the separating gel (the percentage of acrylamide was 10) for $3 \mathrm{~h}$ at room temperature (Biometra, Germany). Silver staining of gels was performed to visualized protein bands (Shevchenko et al., 1996).

\section{Enzyme activity assays}

The analyzed samples for stress enzymes activity assays include the control and two samples of each treatment with the highest growth rate under EMF. The assays of superoxide dismutase (SOD), Catalase (CAT) and Ascorbate peroxidas (APX) were performed on seven-day seedlings. $0.5 \mathrm{~g}$ fresh weights of root and shoot were homogenized separately in liquid $\mathrm{N}_{2}$ with $5 \mathrm{ml}$ of 100 
$\mathrm{mM}$ potassium phosphate buffer $(\mathrm{pH}=7)$ containing $0.1 \mathrm{mM}$ $\mathrm{Na}_{2}$ EDTA and $1 \%(\mathrm{w} / \mathrm{v})$ soluble PVP-10.5 mM; $0.2 \mathrm{mM}$ ASA were added for measurement of APX activity. The slurry was centrifuged at $15000 \times \mathrm{g}$ for $20 \mathrm{~min}$. The supernatant was filtered (Millipore, Mitex $0.5 \mu \mathrm{m}$ ) and used immediately for enzyme analysis. CAT activity was determined by monitoring the decrease in A240 for 1 min in $3 \mathrm{ml}$ of reaction mixture containing $100 \mathrm{mM}$ potassium phosphate buffer $(\mathrm{pH} 7.5)$ and $25 \mathrm{mM} \mathrm{H}_{2} \mathrm{O}_{2}$ and shoot or root extract (Pereira et al., 2003).

CAT activity was expressed based on changes in absorbance against protein content ( $\triangle$ Abs $240 / \mathrm{mg}$ protein). APX activity was determined by monitoring the decrease in A290 for 4 min in $3 \mathrm{ml}$ of reaction mixture containing $100 \mathrm{mM}$ potassium phosphate buffer (pH 7), $0.5 \mathrm{mM}$ Ascorbic Acid (AsA), $0.1 \mathrm{mM} \mathrm{Na} 2 \mathrm{EDTA}, 0.1 \mathrm{mM}$ $\mathrm{H}_{2} \mathrm{O}_{2}$ and shoot or root extract. Correction was made for the oxidation of AsA in the absence of $\mathrm{H}_{2} \mathrm{O}_{2}$ (Nakano and Asada, 1981).

The SOD activity was measured by spectrophotometer as described by Beyer and Fridovich (1986) . The reaction mixture contained $50 \mathrm{mM}$ potassium phosphate buffer $(\mathrm{pH} 7.8), 9.9 \mathrm{mM}$ methionine, $57 \mu \mathrm{m}$ nitro blue tetrazolium (NBT), $0.9 \mu \mathrm{m}$ riboflavin and $0.025 \%(\mathrm{w} / \mathrm{v})$ triton X-100 and appropriate amount of shoot or root extract. The A560 was recorded after a 10 min illumination period. In this assay, 1 unit of SOD is defined as the amount required to inhibit the photo reduction of nitro blue tetrazolium by $50 \%$. The specific activity of SOD was expressed as unit's mg protein of plant (Calatayud et al., 2003). Protein contents were determined in both root and shoot tissues by the method of Bradford (1976), using bovine serum albumin (BSA) as standard.

\section{Statistical analysis}

Morphological difference among the plants grown from treated seeds as well as control plants was determined by Analysis of Variance test (ANOVA), followed by Duncan's multiple range test. Cytological abnormalities were studied using $\mathrm{x}^{2}$ test.

\section{RESULTS AND DISCUSSION}

\section{Growth characteristics}

The highest growth rate, root and shoot length as well as dry and fresh biomass was observed in plants grown from wet seeds pretreated with 3 and $10 \mathrm{mT}$ intensities for a $4 \mathrm{~h}$ exposure time (Shabrangi and Majd, 2009); therefore these two intensities were studied in detail.

The effect of treatment $10 \mathrm{mT}$ in $4 \mathrm{~h}$, on growth parameters including root and shoot tissues, fresh and dry biomass weight showed increase in the early vegetative growth, but in latter stages, these growth parameters decreased significantly. The possible reason for this may be the higher rate of metabolism during seed germination and in the early vegetative growth which requires higher degree of substances consumption and more water absorption under effect of EMFs, as also was reported in lettuce seeds previously treated with magnetic field of magnitude from 1 to $10 \mathrm{mT}$ (Galland and Pazur, 2005).

\section{Morphological characters}

The mean values of morphological characters are given in Table 1. ANOVA test, showed significant difference among the genotypes/treatments used. The number of internodes and number of leaves decreased significantly in the plants grown from exposed grains.

The number of tubular leaves covering the corn was reduced significantly in plants grown from exposed seeds, while the number of rows in the corn increased significantly in plants grown from exposed seeds with 3 $\mathrm{mT}$ for $4 \mathrm{~h}$ exposure time, but reduced in plants grown from exposed seeds with $10 \mathrm{mT}$ for $4 \mathrm{~h}$ exposure time (Table 1).

The weight of 100 seeds was higher in the plants grown from exposed grains. The highest value of weight of 100 seeds occurred in the plants grown from pretreated seeds with $10 \mathrm{mT}$ for $4 \mathrm{~h}$ exposure time (Table 1). The size of yielding seeds of plants grown from pretreated seeds with $3 \mathrm{mT}$ for $4 \mathrm{~h}$ exposure time were higher than control seeds and they were in uniform size. But we observed no uniform size of yielding seeds of plants grown from pretreated seeds with $10 \mathrm{mT}$ for $2 \mathrm{~h}$ exposure time.

Fresh and dry biomass weight of shoot and root of plants grown from exposed grains were reduced significantly compared to the control plants, which may be due to lower rate of protein synthesis in pretreated plants.

\section{Cytogenetic studies}

Mitotic studies were carried out on root meristems of 3 day seedlings. Pre-treated seedlings with $10 \mathrm{mT}$ for $4 \mathrm{~h}$ showed $13 \%$ significant decrease in the cell proliferation rate, while $3 \mathrm{mT}$ for $4 \mathrm{~h}$ exposure time, significantly increased $(3 \%)$ the proliferation rate. Mitotic chromosomal aberration was increased by $13.1 \%$ in the plants raised from wet pre-treated seeds with $10 \mathrm{mT}$ for $4 \mathrm{~h}$, while cytological abnormalities were reduced $(11.48 \%)$ in the plants raised from $3 \mathrm{mT}$ for $4 \mathrm{~h}$ treatment. Cytological aberrations observed include: micronucleus formation, chromosome fragments, laggard chromosomes, and sticky metaphase with bridges formation. Certain combination of EMF and duration like $3 \mathrm{mT}$ for a $4 \mathrm{~h}$ exposure time has high effects of stimulating the plant proliferation compared to control samples and to reduce various types of chromosomal aberrations, while $10 \mathrm{mT}$ intensity for $4 \mathrm{~h}$ exposure time caused opposite results.

It is assumed that $50 / 60-\mathrm{Hz}$ EMFs do not transfer sufficient amounts of energy to cells in order to damage DNA directly conducting to genotoxic effects (Sander et al., 1982). However, certain cellular processes altered by exposure to EMF, such as the generation of free radicals, affect the structure of DNA resulting strand breaks and other chromosomal aberrations, or leading to cytotoxic effects inducing cell death (Piacentini et al., 2001). Genotoxic effects after EMF exposure, such as micronucleus formation (Hanafy et al., 2006), chromosomal aberration and chromatid breaks have been 
Table 1. Effects of EMFs on morphological characters of pre-treated maize plants.

\begin{tabular}{|c|c|c|c|c|c|c|c|c|c|}
\hline Treatment & $\begin{array}{c}\text { Internode } \\
\text { number }\end{array}$ & $\begin{array}{c}\text { Leaf } \\
\text { number }\end{array}$ & $\begin{array}{c}\text { Fresh biomass } \\
\text { weight of shoot }(\mathrm{g})\end{array}$ & $\begin{array}{c}\text { Fresh biomass } \\
\text { weight of root }(\mathrm{g})\end{array}$ & $\begin{array}{c}\text { Dry biomass weight } \\
\text { of shoot }(\mathrm{g})\end{array}$ & $\begin{array}{c}\text { Dry biomass } \\
\text { weight of root }(\mathrm{g})\end{array}$ & $\begin{array}{c}\text { Tubular leaf } \\
\text { number }\end{array}$ & $\begin{array}{c}\text { Row } \\
\text { number }\end{array}$ & Seed weight \\
\hline 1 & 7.95 & 8.75 & 81.71 & 15.29 & 55.6 & 5.66 & 11.7 & 12.7 & 9.7 \\
\hline 2 & $7.4^{*}$ & $8.52^{*}$ & $69.11^{*}$ & 8.06 & $39.95^{\star}$ & 2.8 & $10.3^{*}$ & $14^{*}$ & $14.6^{*}$ \\
\hline 3 & $7.55^{\star}$ & $8.63^{*}$ & $78.00^{*}$ & $10.91^{*}$ & $53.24^{*}$ & $4.1^{*}$ & $10.3^{*}$ & $11.3^{*}$ & $23.15^{*}$ \\
\hline
\end{tabular}

*Significant from control at 0.05 level (t-test). 1 = Control plants, 2 = Plants raised from treated seeds with $3 \mathrm{mT}$ for $4 \mathrm{~h}$ and $3=\mathrm{Plants}$ raised from treated seeds with $10 \mathrm{mT}$ for $4 \mathrm{~h}$.

reported by different investigators (Ruediger, 2009; Nirmala and Rao, 1996). The bridges would lead to gene duplication at one pole and deletion at the other pole, while laggards may be distributed randomly to either pole producing monosomic or trisomic cells (Galland and Pazur, 2005). Different chromo-somal aberrations, such as laggard chromosome and micronuclei may lead to a loss of some genetic material (Hanafy et al., 2006).

Meiotic analysis concerning chiasma frequency and distribution as well as chromosomes association among control plants and plants grown from exposed seed are given in Table 2. ANOVA test revealed significant difference $(p<0.01)$ for all meiotic characters studied among genotypes. The mean value of total, terminal and intercalary chiasmata increased significantly in the plants grown from exposed seeds to $3 \mathrm{mT}$ for a $4 \mathrm{~h}$ exposure time, while the same values were reduced in the plants grown from exposed seeds to $10 \mathrm{mT}$ for a $4 \mathrm{~h}$ exposure time. The mean number of ring bivalent also increased significantly in the plants grown from treated seeds, while the mean values of rod bivalent, quadrivalents and univalents reduced significantly in the plants grown from treated seeds. Chiasma frequency and distribution are genetically controlled (Fadaei et al., 2010), and significant change in these indicates the effect of EMFs on genetic recombination.
Meiotic abnormalities observed in the plants grown from exposed seeds include: Chromosome stickiness, bridges, laggards and disorganized chromosomes (Figure 1A to G). Disorganized chromosomes were the most phenomenon observed in meiotic cell divisions. Lagging chromosomes were recorded at anaphase-I stage in both treatments. Chromosome bridges resulting from stickiness were mostly observed in anaphase-I as well as telophase-I stage. Stickiness occurred among two pairs of chromosome and more, leading to the formation of complete clump (Figure $1 \mathrm{~F}$ and $\mathrm{G}$ ).

Bridges can be originated from chromosome with two centromers or resulting from stickiness. Genetic as well as environmental factors such as EMFs are assumed to be the reason for chromosome stickiness in various species (Ruediger, 2009). Therefore, difference in the percentage of stickiness of pretreated plants with control line would be the result of genomic-environmental interaction as the main reason for the occurrence of chromosome stickiness. The thickness of bridges and number of chromosomes involved in their formation differed in meiocytes of pretreated plants and control line.

Other meiotic abnormalities observed were the occurrence of aneuploidy in treated plants, which would be the result of cytomixis (Figure $1 \mathrm{H}$ and $\mathrm{I}$ ), cytogenetic study of control plants did not show the occurrence of aneuploidy.
The percentage of infertile pollen increased significantly in pretreated plants compared to control line. Due to cytomixis, formation of cells with missing chromatin materials leads to the formation of abnormal tetrads, which resulted in high intensity in pretreated plants.

Cytomixis has been reported in several plant species leading to the formation of aneuploid as well as polyploid meiocytes (Sheidai et al., 2001). Cytomixis leads usually to aneuploidy or reduction in fertility of plants, therefore it is considered to be of less evolutionary significance, however, it may bring about new genetic variability by producing aneuploid gametes and new phenotypic characters as reported in other plants (Smith and Mays, 1984).

B-chromosomes are accessory chromosomes found in many species of plants including $Z$. mays species. The B-chromosomes shows numerical polymorphism; when present in high number may reduce viability of plants possessing them but when present in low number may benefit the plants having B-chromosomes. B-chromosomes affect the frequency and distribution of chiasmata. Therefore, they would affect meiotic behavior or indirectly affect genes controlling meiosis present in the A-chromosomes (Sheidai and Inamdar, 1993).

The number of B-chromosome in pretreated plants was higher than control plants studied, showing significant induction in the intercalary 
Table 2. Meiotic characters in Z. mays tratments studied.

\begin{tabular}{|c|c|c|c|c|c|c|c|c|c|c|c|c|c|}
\hline Sample & TX & IX & TOX & RB & ROD & IV & I & DC & L1 & B & C & $\mathbf{M}$ & IP \\
\hline 1 & 9.703 & 2.781 & 12.487 & 5.405 & 3.162 & 0.135 & 2.476 & 0 & 3.7 & 3.33 & 6.3 & 0 & 0.4 \\
\hline 2 & 11.271 & 4.104 & 15.375 & 7.188 & 1.479 & 0.063 & 1.250 & 25 & 25 & 25 & 7.7 & 11 & 14 \\
\hline 3 & 9.262 & 2.905 & 12.167 & 5.667 & 1.810 & 0.071 & 1.270 & 29.7 & 30 & 12.3 & 18 & 12 & 49.7 \\
\hline
\end{tabular}

*Significant from control at 0.05 level (t-test). 1 = Control plants, $2=$ Plants raised from seed pretreated with $3 \mathrm{mT}$ for $4 \mathrm{~h}$ and $3=\mathrm{Plants}$ raised from seed pretreated with $10 \mathrm{mT}$ for $4 \mathrm{~h}$.

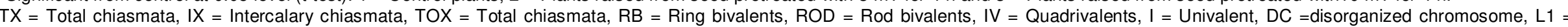
Anaphase-I laggards, $B=$ Anaphase- $I$ Bridges, $M=$ Micronuclei formation, $C=$ Clumping, $I P=$ infertile pollen.

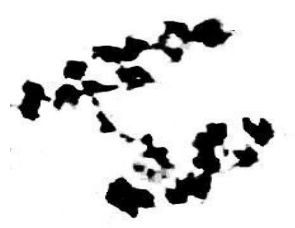

A

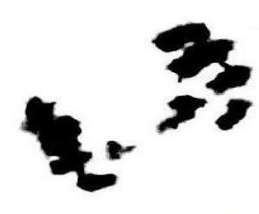

$\mathbf{E}$

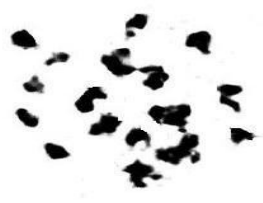

B

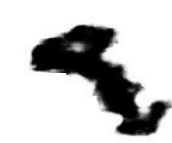

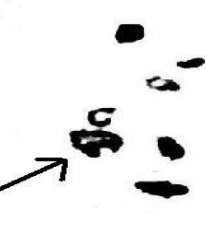

(1)

$\mathrm{C}$

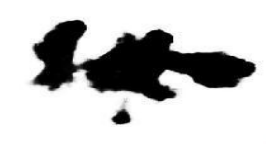

$\mathbf{F}$

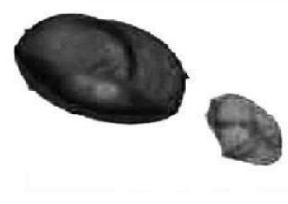

$\mathbf{J}$

Figure 1. Representative meiotic cells in maize treatments studied. $A=$ Anaphase-I bridge in control plants; $B$ = Meiocyte showing extra chromosomes in plants raised from seed pretreated with $3 \mathrm{mT}$ for $4 \mathrm{~h} ; \mathrm{C}=$ Meiocyte showing quadrivalent (arrow), in plants raised from seed pretreated with10 $\mathrm{mT}$ for $4 \mathrm{~h}$; $\mathrm{D}=$ Meiocyte showing quadrivalent (arrow), in plants raised from seed pretreated with $3 \mathrm{mT}$ for $4 \mathrm{~h} ; \mathrm{E}=$ Meiocyte showing laggard chromosomes in plants raised from seed pretreated with $10 \mathrm{mT}$ for $4 \mathrm{~h} ; \mathrm{F}=$ Meiocyte showing chromosome clump in plants raised from seed pretreated with $10 \mathrm{mT}$ for $4 \mathrm{~h} ; \mathrm{G}=$ Meiocyte showing chromosome clump in plants raised from seed pretreated with $3 \mathrm{mT}$ for $4 \mathrm{~h} ; \mathrm{H}=$ Meiocyte showing aneuploidy (chromosome number reduction, $2 \mathrm{n}-2$ ) and B-chromosome (arrow) in plants raised from seed pretreated with10 $\mathrm{mT}$ for $4 \mathrm{~h}$; I= Meiocyte showing aneuploidy (chromosome number reduction, $2 n-1)$ in plants raised from seed pretreated with $10 \mathrm{mT}$ for $4 \mathrm{~h} ; \mathrm{J}=$ Infertile pollen grains (smaller size pollen grain) in plants raised from seed pretreated with $10 \mathrm{mT}$ for $4 \mathrm{~h}$. Scale bar $=10 \mu \mathrm{m}$. 
Table 3. The total protein of the unexposed and the seeds exposed to the specific electromagnetic fields (Amount of total protein in $\mu \mathrm{g} / 50 \mu \mathrm{g}$ fresh biomass) (Mean \pm Standard error).

\begin{tabular}{lcc}
\hline Exposure case & Crude protein in shoot & Crude protein in root \\
\hline Wet treated seeds $(3 \mathrm{mT}, 4 \mathrm{~h})$ & $61.833 \pm 2.088^{*}$ & $33.083 \pm 12.667^{*}$ \\
Wet treated seeds $(10 \mathrm{mT}, 4 \mathrm{~h})$ & $60.667 \pm 5.805^{\star}$ & $20.167 \pm 9.208^{\star}$ \\
Control & $74 \pm 7.095$ & $58.5 \pm 9.756$ \\
\hline
\end{tabular}

*Significant from control at 0.05 level (t-test).

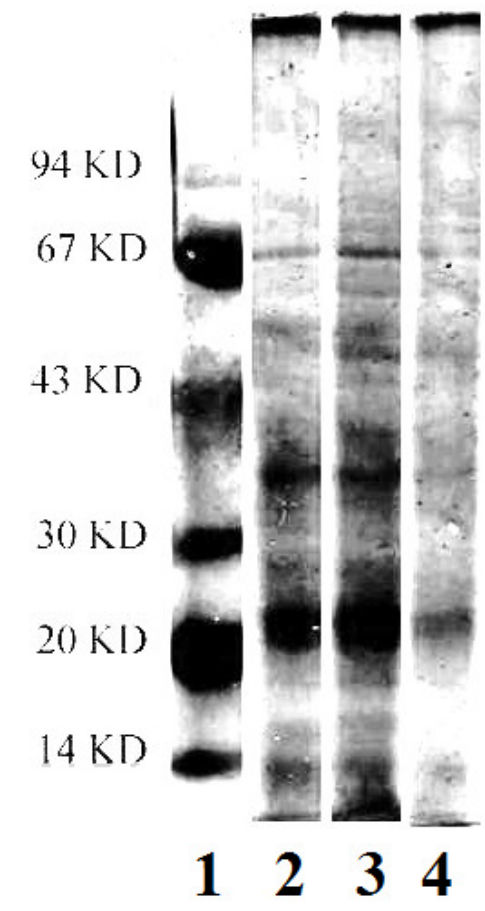

Shoot

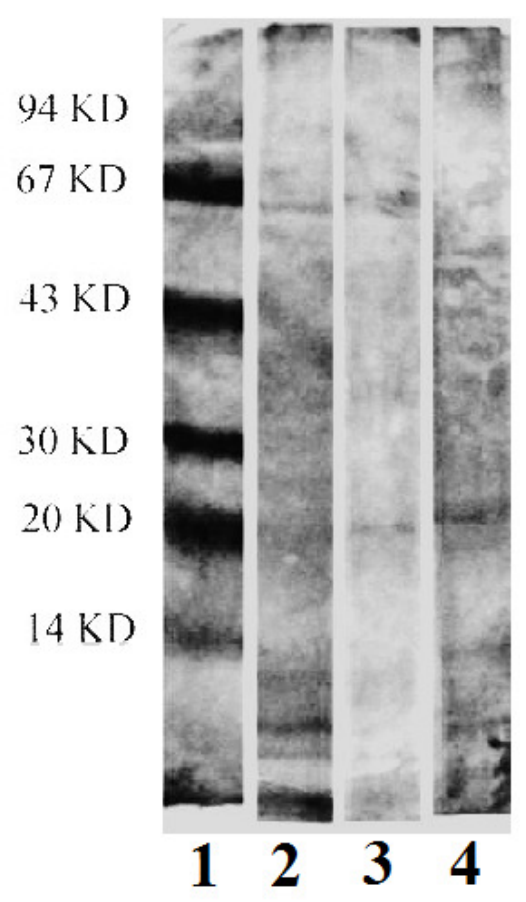

Root

Figure 2. Protein analysis by silver-stained SDS-PAGE in maize treatments. Lanes 1-4= size marker, control plants, plants raised from $3 \mathrm{mT}$ for $4 \mathrm{~h}$ and plants raised from $10 \mathrm{mT}$ for $4 \mathrm{~h}$, respectively.

chiasmata and mean number of ring bivalents.

Therefore, the genomic changes occurred by electromagnetic fields in maize caused some morphological changes in this plant as well as changing recombination values and bringing about cytological alterations including aneuploidy production, which may be used in breeding of maize plant as suggested in other crop plants (Pavela and Dorina-Emilia, 2005).

\section{SDS-PAGE results}

Table 3 explains the total protein content of the exposed seedlings and the control plants studied. The amount of the total protein decreased for the exposed seedlings as compared to the unexposed ones $(P<0.05)$. Scanning profiles of the electrophoretic preparation showed that the number and intensity of the protein bands differed in the pre-treated samples having molecular weight in the range of 15 to $97 \mathrm{KDa}$ (Figure 2). The number of bands in shoot tissue pre-treated with $3 \mathrm{mT}$ for a $4 \mathrm{~h}$ exposure time increases compared to control line, while shoot tissue pre-treated with $10 \mathrm{mT}$ for a $4 \mathrm{~h}$ exposure time, decreased in the number of bands compared to control line. The number of bands in root tissues in both treatments ( 3 and $10 \mathrm{mT}$ for $4 \mathrm{~h}$ exposure time), decreased compared to the control line. Some bands in electrophoretic profile disappeared that would be the result of protein degradation (Table 4). The changes in the seedlings protein electrophoretic profiles would be the result of occurrence of either gene mutation or indication of cytological abnormalities. 
Table 4. SDS-PAGE Protein data.

\begin{tabular}{|c|c|c|c|c|c|c|c|c|c|c|c|c|c|c|c|c|}
\hline Protein weight KD & 80 & 70 & 67 & 60 & 50 & 40 & 35 & 30 & 27 & 25 & 20 & 18 & 15 & 14 & 10 & 85 \\
\hline shoot control & 0 & 0 & 1 & 1 & 1 & 0 & 1 & 0 & 0 & 1 & 1 & 1 & 1 & 1 & 0 & 00 \\
\hline shoot $3 \mathrm{mT}, 4 \mathrm{~h}$ (wet) & 1 & 1 & 1 & 1 & 1 & 1 & 1 & 1 & 0 & 1 & 1 & 1 & 1 & 1 & 0 & 00 \\
\hline shoot $10 \mathrm{mT}, 4 \mathrm{~h}$ (wet) & 1 & 1 & 1 & 0 & 0 & 0 & 1 & 0 & 0 & 0 & 1 & 0 & 0 & 1 & 0 & 00 \\
\hline root control & 0 & 0 & 1 & 1 & 1 & 1 & 1 & 0 & 1 & 0 & 0 & 1 & 0 & 1 & 0 & 11 \\
\hline root $3 \mathrm{mT}$, 4h (wet) & 0 & 0 & 0 & 1 & 1 & 0 & 0 & 1 & 1 & 0 & 0 & 1 & 0 & 0 & 1 & 01 \\
\hline root $10 \mathrm{mT}, 4 \mathrm{~h}$ (wet) & 0 & 0 & 1 & 1 & 1 & 1 & 0 & 0 & 1 & 0 & 0 & 1 & 0 & 0 & 0 & 10 \\
\hline
\end{tabular}

\section{Enzymes activity assays}

Table 5 explains the activity of stress enzymes of the exposed seedlings and the control seedlings studied. The activity of SOD in 7 day seedlings grown from wet pretreated seeds with $3 \mathrm{mT}$ for 4 $\mathrm{h}$ exposure time increased significantly in both root and shoot tissues. Likewise, pretreated seeds with $10 \mathrm{mT}$ for $4 \mathrm{~h}$ exposure time increased the level of SOD activity in root and tissue. Both treatments with magnitudes of 3 and $10 \mathrm{mT}$ for 4 $\mathrm{h}$ exposure time in both tissues of pretreated seedlings remarkably increased the activity of CAT, compared to the control one. Pretreated seedlings with EMFs either 3 or $10 \mathrm{mT}$ magnitudes showed significant increase in the activity of APX, compared to the corresponding control seedlings. We observed overall stimulating effects of both treatments including 3 and $10 \mathrm{mT}$ intensities for $4 \mathrm{~h}$ exposure time on the activities of stress enzymes of both root and shoot tissues of maize.

In general, we observed an overall stimulating effects of EMFs on the activity of all stress enzymes including SOD, CAT and APX increased, while this increase in root tissue was higher than that of shoot tissue $(P<0.05)$. On the other hand, increase in the stress enzymes activity in pretreated seedlings with $10 \mathrm{mT}$ intensity for $4 \mathrm{~h}$ exposure time was lower than that in pretreated seedlings with $3 \mathrm{mT}$ intensity for $4 \mathrm{~h}$ exposure time. There was an exception in the activity of APX of root tissue. Therefore, the ability of seedlings to protect against higher intensity of this stress would not be as well as lower intensity.

One of such theories that would explain the biological effects of electromagnetic fields is based on the possible effects on the formation of free radicals due to electromagnetic field exposure (Piacentini et al., 2001). Enzymatic activity will be increased due to the activation of enzymatic molecules or increased gene expression (Tkalec et al., 2005). We believe the activation of enzymatic molecules that contain heme in their structure, like CAT and APX would change under effects of EMFs. It seems these enzymes that contain heme in their structure would be more exited under effects of EMFs. Some studies have suggested that electromagnetic field exposure could cause both the increase in the concentration and oscillating of free radicals (Scaiano et al., 1995). It is assumed that in order to obtain a powerful scavenging of toxic oxygen forms, the overproduction of the $\mathrm{H}_{2} \mathrm{O}_{2}$ generate SOD. Furthermore, CAT or APX metabolize in order to have effective defense against the overproduction of toxic oxygen forms in plants exposed to environmental stresses, such as EMFs (Sen Gupta et al., 1993). Our observations showed that in pretreated seedlings of maize, the action of high levels of SOD at both 3 and $10 \mathrm{mT}$ is multiplied along with a higher CAT activity during the early stages. Note that the latter enzyme participates in the $\mathrm{H}_{2} \mathrm{O}_{2}$-scavenging of APX, which efficiency could help prevent oxidative injury occurring with EMFs. It seems that these enzymes contribute to lower the deleterious effects of $\mathrm{H}_{2} \mathrm{O}_{2}$ and above all the risk of $\mathrm{OH}^{\circ}$ formation, promoting survival in plants (Piacentini et al., 2001).

This phenomenon in root tissue of maize occurred stronger than that in shoot tissue. As a result, root tissue seems to be more sensitive than shoot tissue and more potential than shoot tissue to response against ELF-EMFs as environmental stress.

\section{Conclusion}

All results suggested that maize plants pretreated with 3 and $10 \mathrm{mT}$ for $4 \mathrm{~h}$ exposure time showed less growth than control plants. Cytogenetic studies indicated that $3 \mathrm{mT}$ for $4 \mathrm{~h}$ exposure time treatment induced the mean value of genetic recombination $(P<0.05)$. However, further mechanistic studies would be needed to enlighten 
Table 5. Enzyme activity assays (Mean \pm Standard error).

\begin{tabular}{|c|c|c|c|c|c|c|}
\hline Exposure case & $\begin{array}{l}\text { CAT activity in } \\
\text { shoot }(\mu \mathrm{g})\end{array}$ & $\begin{array}{l}\text { CAT activity in } \\
\text { root }(\mu \mathrm{g})\end{array}$ & $\begin{array}{c}\text { APX activity in } \\
\text { shoot }\end{array}$ & $\begin{array}{l}\text { APX activity in } \\
\text { root }\end{array}$ & $\begin{array}{c}\text { SOD activity in } \\
\text { shoot }\end{array}$ & $\begin{array}{c}\text { SOD activity in } \\
\text { root }\end{array}$ \\
\hline Wet treated seeds ( $3 \mathrm{mT}, 4 \mathrm{~h})$ & $6.57 \pm 1.27^{\star}$ & $36.5 \pm 8.4^{*}$ & $5.4 \pm 0.29^{\star}$ & $8.2 \pm 0.33^{*}$ & $39 \pm 6.8^{*}$ & $177 \pm 26.1^{*}$ \\
\hline Wet treated seeds $(10 \mathrm{mT}, 4 \mathrm{~h})$ & $4.8 \pm 0.2^{*}$ & $15.67 \pm 1.3^{*}$ & $3.6 \pm 0.23^{*}$ & $17.8 \pm 0.42^{*}$ & $13.3 \pm 2.6^{*}$ & $60.38 \pm 25.13$ \\
\hline Control & $2.53 \pm 0.37$ & $6.4 \pm 0.4$ & $2.88 \pm 0.12$ & $4 \pm 0.58$ & $13.7 \pm 5.12$ & $4.14 \pm 1.1$ \\
\hline
\end{tabular}

*Significant from control at 0.05 level.

these effects.

\section{REFERENCES}

Angel DST, De Souza A, Garcia D, Sueiro L, Licea L, Porras E (2005). Pre-sowing magnetic treatment of tomato seeds effect on the growth and yield of plants cultivated late in the season. Spanish J. Agric. Res. 3(1): 113-122.

Bhatnagar D, Deb AR (1977). Some aspects of pregermination exposure of wheat seeds to magnetic field .Seed Germination and early growth. Seed Res. 5: 129-137.

Bradford MB (1976). A rapid and sensitive method for the quantitation of microgram quantities of protein utilizing the principale of protein dye binding. Ana. Biochem. 72: 248254.

Calatayud A, Iglesias D, Talon M, Barreno E (2003). Effect of 2-month ozone exposure in spinach leaves on photosynthesis, antioxidant systems and lipid peroxidation. Plant Physiol. Biochem. 41: 839-845.

Fadaei F, Sheidai M, Asadi M (2010).Cytological study the genus Arenaria L. (Caryophyllaceae). Caryologia, 63(2): 149-156.

Fridovich I (1986). Superoxide dismutases. Adv. Enzymol. Relat. Areas Mol. Biol. 58: 61-97.

Galland P, Pazur A (2005). Magnetoreception in plants. J. Plant Res. 118(6): 371-389.

Hanafy MS, Mohamed HA, Abd El-Hady EA (2006). Effect of Low Frequency Electric Field on growth characteristics and protein molecular structure of wheat plant. Romanian J. protein molecular structur
Biophy. 16(4): 253-271.

Moon JD, Chung HS (2000). Acceleration of germination of tomato seed by applying AC electric and magnetic fields. J. Electrostatics, 48: 103-114.

Nakano Y, Asada K (1981). Hydrogen peroxide is scavenged by ascorbate specific peroxidase in spinach chloroplast. Plant Cell Physiol. 22: 867-880.
Nirmala A, Rao P N (1996). Genetic of chromosome numerical mosaism in higher plants. Nucleus, 39: 151-175.

Pavela A, Creanga D, Dorina-Emilia C (2005). Chromosomal aberrations in plants under magnetic fluid influence. J. Magnetism Magnetic Materials J. 289: 469-472.

Pereira Ede J, Panek AD, Eleutherio EC (2003). Protection against oxidation during dehydration of yeast. Cell Stress Chaperones, 8: 120-124

Piacentini MP, Fraternale D, Piatti E, Ricci D, Vetrano F, Dachà $M$, Accorsi $A$ (2001). Senescence delay and change of antioxidant enzyme levels in Cucumis sativus $L$. etiolated seedlings by ELF magnetic fields. Plant Sci. 161(1): 45-53.

Pittman UJ (1977). Effect of magnetic seed treatment on yields of barley, wheat, and oats in southern Alberta. Canad. J. Plant Sci. 57: 37-45.

Ruediger HWR (2009). Genotoxic effects of radiofrequency electromagnetic fields. Pathophysiology, 16: 89-102.

Sander R, Brinkmann J, Ku"hne B (1982). Laboratory studies on animals and human beings exposed to $50 \mathrm{~Hz}$ electric and magnetic fields. CIGRE, International Cong Large High Voltage Electric Syst. September 1-9, Paris, Abstract number 36-01.

Scaiano JC, Cozens FL, Mohtat N (1995). Development of a model and application of the radical pair mechanism to radicals in micelles. Photochem. Photobiol. 62: 818-829.

Sen Gupta SA, Webb RP, Holaday AS, Allen RD (1993) Overexpression of superoxide dismutase protects plants from oxidative stress. Plant Physiol. 103: 1067-1073.
Shabrangi A, Majd A (2009). Comparing Effects of Electromagnetic Fields $(60 \mathrm{~Hz})$ on seed germination and seedling development in Monocotyledons and Dicotyledons. Progress In Electromagnet. Res. Symp. Proceed. Moscow, Russia, August 18-21.

Sheidai M, Inamdar AC (1993). B-chromosomes in Asparagus L. Nucleus, 44: 141-144.

Shevchenko A, Jensen O, Podtelejnikov AV, Sagliocco F, Willm M, Vorm O, Mortensen P, Shevchenko A, Boucherie H, Mann M, Proc Natl(1996). Acad. Sci. 93: 14440-14445.

Smith SD, Mays R (1984). Effect of pulsed magnetic fields on root development in plant cuttings. Bioelectrochem. Bioenerg. 12: 567-573.

Tkalec M, Malarić K, Pevalek-Kozlina B (2005). Influence of 400,900 and $1900 \mathrm{MHz}$ electromagnetic fields on Lemna minor growth and peroxidase activity. Bioelectromagnetics, 26(3): 185-193. 